University of Nebraska - Lincoln

DigitalCommons@University of Nebraska - Lincoln

Publications from USDA-ARS / UNL Faculty

U.S. Department of Agriculture: Agricultural

Research Service, Lincoln, Nebraska

2017

The history and current status of glyphosate

Stephen O. Duke

USDA-ARS, stephen.duke@ars.usda.gov

Follow this and additional works at: https://digitalcommons.unl.edu/usdaarsfacpub

Duke, Stephen O., "The history and current status of glyphosate" (2017). Publications from USDA-ARS /

UNL Faculty. 1766.

https://digitalcommons.unl.edu/usdaarsfacpub/1766

This Article is brought to you for free and open access by the U.S. Department of Agriculture: Agricultural Research Service, Lincoln, Nebraska at DigitalCommons@University of Nebraska - Lincoln. It has been accepted for inclusion in Publications from USDA-ARS / UNL Faculty by an authorized administrator of DigitalCommons@University of Nebraska - Lincoln. 


\title{
The history and current status of glyphosate
}

\section{Stephen O Duke* ${ }^{*}$}

\begin{abstract}
Glyphosate is the only herbicide to target the enzyme 5-enolpyruvyl-3-shikimate phosphate synthase (EPSPS). It is a high use rate, non-selective herbicide that translocates primarily to metabolic sinks, killing meristematic tissues away from the application site. Its phloem-mobile properties and slow action in killing weeds allow the herbicide to move throughout the plant to kill all meristems, making it effective for perennial weed control. Since commercialization in 1974, its use has grown to dominate the herbicide market. Much of its use is on transgenic, glyphosate-resistant crops (GRCs), which have been the dominant transgenic crops worldwide. GRCs with glyphosate provided the most effective and inexpensive weed management technology in history for a decade or more. However, as a consequence of the rapid increase in glyphosate-resistant (GR) weeds, the effectiveness of glyphosate use in GRCs is declining. Critics have claimed that glyphosate-treated GRCs have altered mineral nutrition and increased susceptibility to plant pathogens because of glyphosate's ability to chelate divalent metal cations, but the complete resistance of GRCs to glyphosate indicates that chelating metal cations do not contribute to the herbicidal activity or significantly affect mineral nutrition. The rates of increases in yields of maize, soybean, and cotton in the USA have been unchanged after high adoption rates of GRCs. Glyphosate is toxic to some plant pathogens, and thereby can act as a fungicide in GRCs. Ultra-low doses of glyphosate stimulate plant growth in glyphosate-susceptible plants by unknown mechanisms. Despite rapid and widespread increases in GR weeds, glyphosate use has not decreased. However, as GR weeds increase, adoption of alternative technologies will eventually lead to decreased use.

Published 2017. This article is a U.S. Government work and is in the public domain in the USA.
\end{abstract}

Keywords: glyphosate; 5-enolpyruvyl-3-shikimate phosphate synthase (EPSPS); herbicide-resistant crop; glyphosate resistance

\section{INTRODUCTION}

Glyphosate is the most successful herbicide in history. ${ }^{1}$ This discussion briefly chronicles how this came to be and provides some speculation about its future. Glyphosate was a highly successful non-selective herbicide before the introduction of glyphosate-resistant crops (GRCs); however, the introduction of GRCs greatly increased its use in those countries approving their cultivation (e.g. Figs 1 and 2 ). ${ }^{2}$ Almost $90 \%$ of the land area covered by transgenic crops worldwide is planted in herbicide-resistant crops (HRCs), and almost all of these have been GRCs. ${ }^{3}$ The economic reward to farmers who adopted the GRC technology was the principal driver for the phenomenal success of this technology. ${ }^{4-6}$ All of this has made glyphosate the most used pesticide worldwide.

Glyphosate has been the focus of intensive scientific study and product innovation. The number of scientific publications and patents involving glyphosate has increased to almost 20000 in the past 40 years, with most of them in the past 15 years (Fig. 3). Glyphosate is beginning to rival 2,4-D (2,4-dichlorophenoxoyacetic acid) as the most studied herbicide in history.

The third decade of the use of GRCs has begun, and the HRC scenario is becoming more complex as a consequence of the evolution of weed resistance to glyphosate and the introduction of new HRCs. After about 10 and 20 years of GRC use, I analyzed the then current state and potential future of GRCs. ${ }^{7,8}$ Dramatic changes are occurring in the utility of glyphosate for GRC use that could impact prospects for its future. This perspective summarizes the history and current status of glyphosate after more than two decades of growing GRCs. I discuss the rapidly changing aspects of evolution of resistance to glyphosate and competing and complementary herbicides, as well as new weed management technologies that might influence future use of glyphosate.

\section{PRE GLYPHOSATE-RESISTANT CROPS}

Glyphosate was commercialized in 1974, when new herbicide modes of action were being introduced every 2 to 3 years. ${ }^{9,10}$ Prior to the introduction of GRCs, glyphosate use was similar to that of the bipyridinium herbicides, paraquat and diquat, which were first commercialized over a decade earlier than glyphosate. ${ }^{11}$ Bipyridiniums and glyphosate are widely used non-selective herbicides that are essentially inactive in soil. Glyphosate continues to be used in non-crop situations such as on roadsides, on and beside railway tracks, and in pre- and post-cropping of fields, as well as for control of vegetation of the understory in trees and orchard crops, with care that none drifts on to the green vegetation of the crop. Although more expensive than paraquat, glyphosate has several advantages. Unlike paraquat, which is a rapidly acting contact herbicide, glyphosate is slow acting and readily translocates to meristems distant from the treated foliage. ${ }^{12}$ Glyphosate's excellent systemic properties allow the weed to be killed by application

Correspondence to: SO Duke, USDA, ARS, Natural Products Utilization Research Unit, Room 1012, Thad Cochran Research Center, University, MS 38677, USA. Email:stephen.duke@ars.usda.gov

United States Department of Agriculture, Agricultural Research Service, Natural Products Utilization Research Unit, Thad Cochran Research Center, University, MS, USA 
Estimated Agricultural Use for Glyphosate, Epest-Low 1994
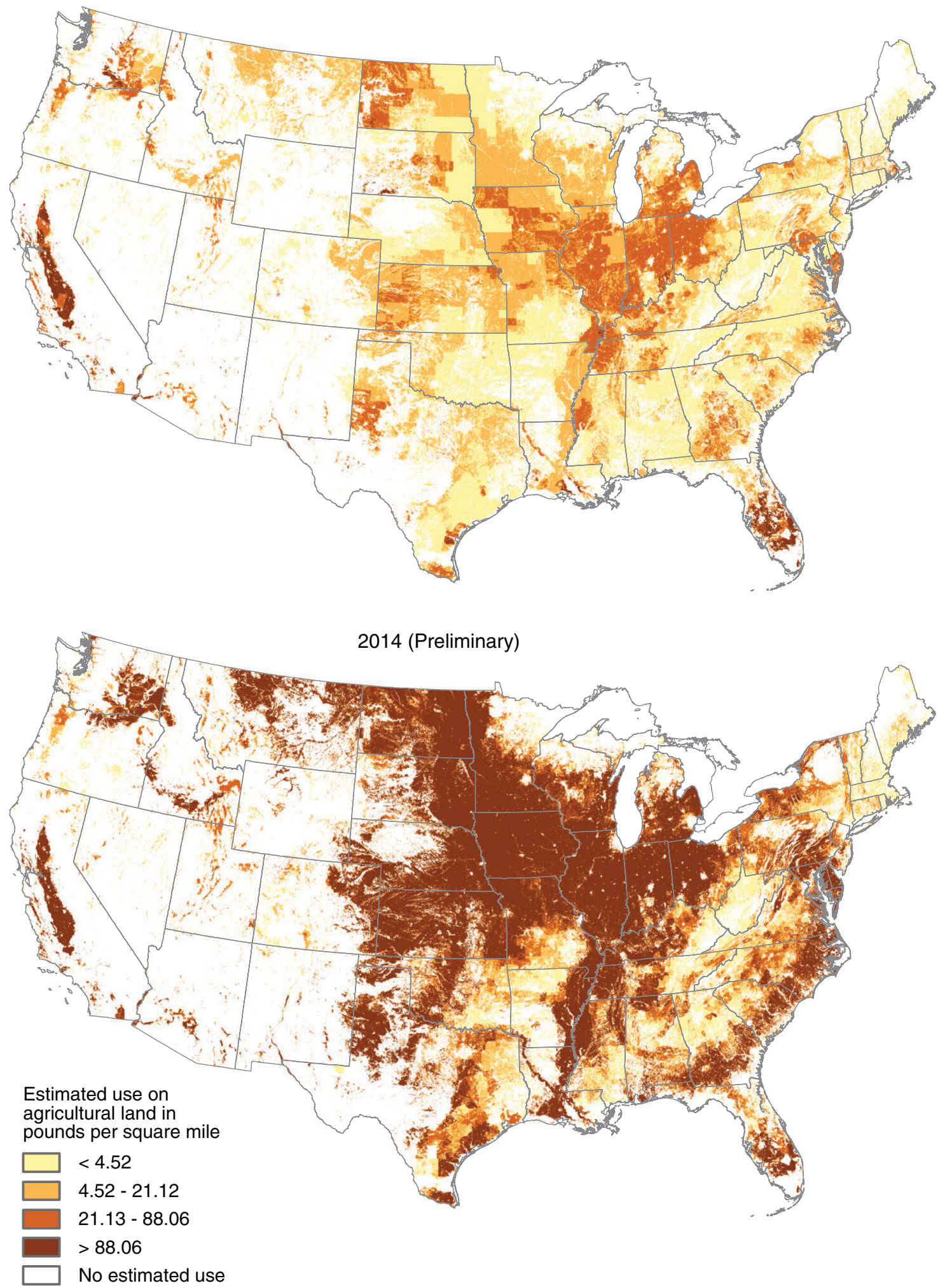

Figure 1. Geographic distribution and estimates of glyphosate use in 1994 and 2014 in the USA. ${ }^{2}$ 


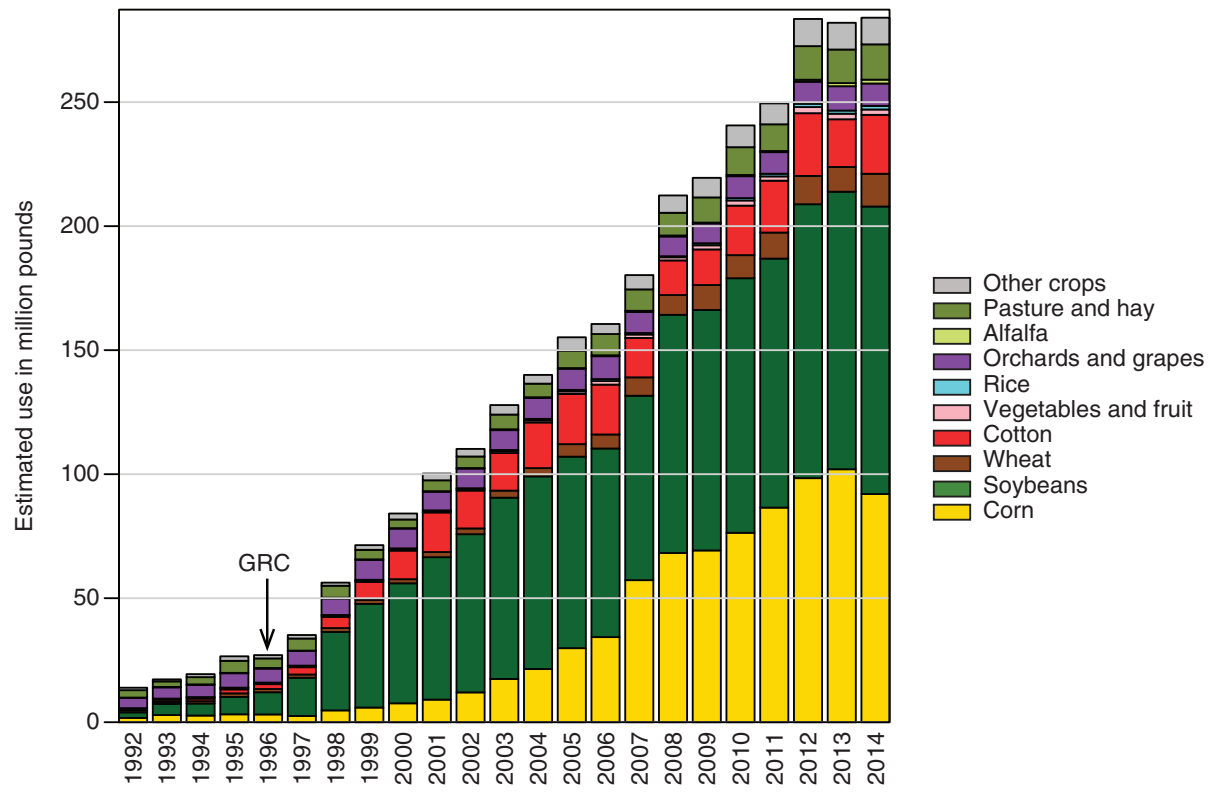

Figure 2. Glyphosate use in the USA by year and crop. The arrow denotes the introduction of GRCs. ${ }^{2}$

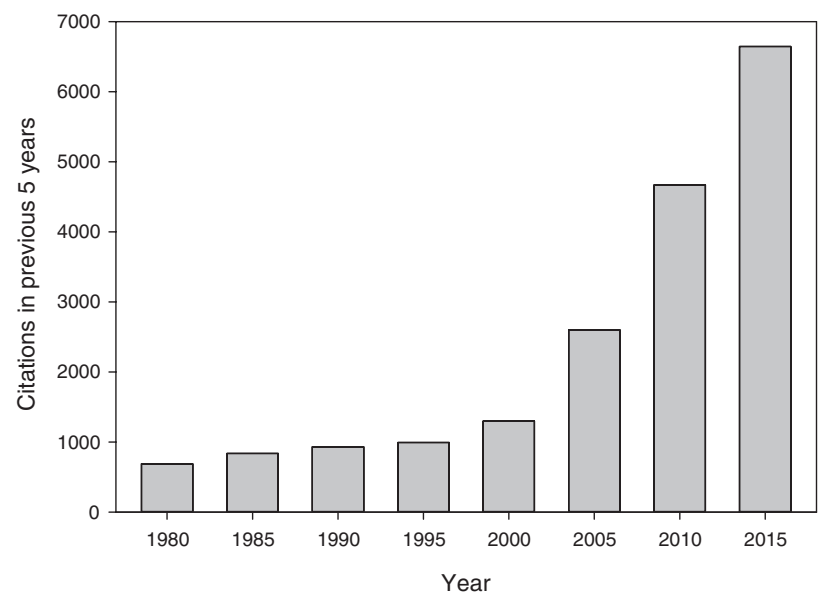

Figure 3. Papers and patents retrieved in SciFinder using the keyword 'glyphosate'. Each bar represents the total in that year plus the previous 4 years.

to only a small percentage of the weed's foliage. Thus, glyphosate is much more effective than paraquat in preventing re-growth from meristems, and therefore has a tremendous advantage in killing perennial weeds. Lastly, the bipyridiniums are probably the most acutely toxic herbicides to vertebrates, ${ }^{13}$ but extensive investigations have shown that glyphosate and its degradation product aminomethylphosphonic acids (AMPA) have very low acute and chronic toxicity, ${ }^{14-17}$

Glyphosate is a superior herbicide, ${ }^{1}$ but glyphosate's high level of phytotoxicity to crops limited its use. Attempts were made to use glyphosate in row crops while avoiding contact with the crops by employing application devices that did not use broadcast spraying, such as shielded sprayers and rub-on (e.g. rope wick and carpet) applicators, and by applying glyphosate as spot treatments to individual weeds. ${ }^{18,19}$ However, as a result of its highly systemic properties, only a small amount of glyphosate on the crop, as a result of drift or direct application, can injure or kill a crop plant. These application technologies were not widely adopted because of technical problems in getting the herbicides to all of the weeds and frequent, unacceptable levels of crop damage. Making crops resistant to glyphosate via biotechnology solved the problem.

\section{THE GOLDEN AGE OF WEED MANAGEMENT; THE FIRST TEN YEARS OF GLYPHOSATE-RESISTANT CROPS}

The first commercialized HRCs in 1995, bromoxynil-resistant and glufosinate-resistant canola, had little impact, but the introduction in 1996 of the first GRC, glyphosate-resistant (GR) soybean, started a weed management revolution. ${ }^{1,7,8,20}$ Within 10 years, adoption of GR soybean in the USA was $>90 \%$, followed later by $>90 \%$ adoption of GR cotton and maize, with a plateau of all three at $>90 \%$ by 2014 (Fig. 4). Adoption of GR soybean in Argentina was more rapid, ${ }^{21}$ and the adoption rate in Brazil has also been high. ${ }^{22}$ Adoption rates of other GR crops (alfalfa, canola, and sugarbeets) in the USA has been high too. In the case of GR sugarbeets in the USA, the adoption rate was $95 \%$ within 3 years (commercialized in 2007). ${ }^{23}$

This technology was a boon for farmers, as it simplified and reduced the cost of weed management, while giving better results than the multiple herbicides previously needed to give adequate weed management in these crops. The positive impact was perhaps even greater for small farmers who had neither the expertise nor budget for consultants to generate prescription herbicide remedies for specific weed problems. The economic and efficacy reasons for this outstanding success have been detailed in many publications. ${ }^{1,4,8,20,21,24-26}$ Furthermore, this technology reduced the environmental impact of weed management through reductions in tillage, fossil fuel use, and the use of more toxic herbicides, detailed in many previous reviews..$^{27-30}$ It was the golden age of weed management with simple, economical, and outstandingly effective weed management with reduced environmental impact, using a herbicide active ingredient that was considered to be virtually non-toxic to humans. 


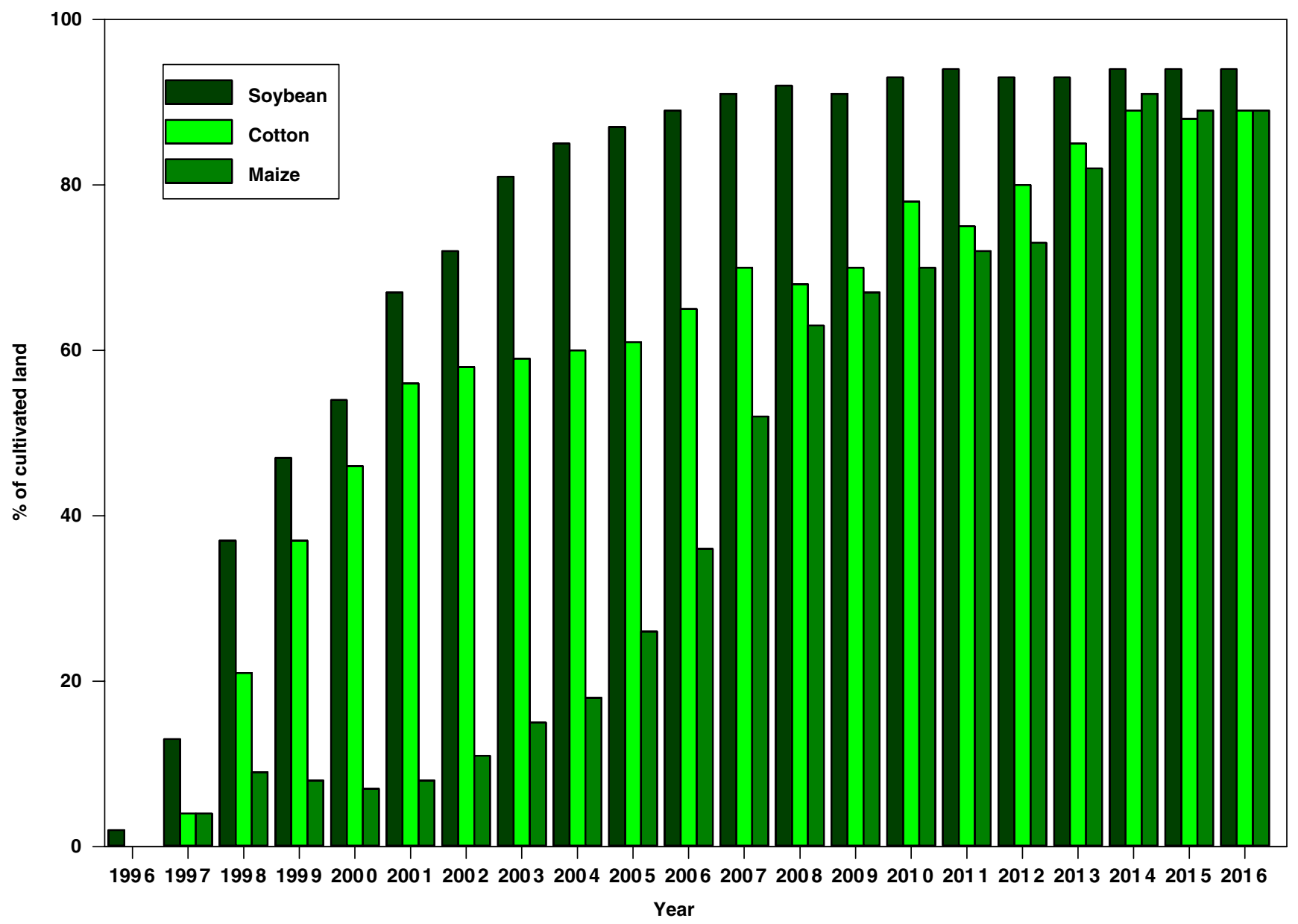

Figure 4. GRC adoption in soybean, maize and cotton by year in the USA.

In the USA, use of glyphosate climbed rapidly after the introduction of GRCs (Figs 1 and 2). Concomitantly, use of other herbicides that had been used with these crops plummeted. ${ }^{31}$ For example, use of the mostly soybean protoporphyrinogen oxidase inhibitor herbicide acifluorfen was greatly reduced after GR soybeans were introduced in 1996 (Fig. 5). Similar reductions occurred with other herbicides that had been used in the crops that had been made glyphosate resistant. The phenomenal success for GRCs significantly devalued the market for other herbicides, leading to reductions in investment in herbicide discovery, with at least one company abandoning herbicide discovery efforts. This was at the time when the introduction of new herbicide modes of action had stopped ${ }^{10}$ and weed resistance to existing herbicides' modes of action had begun a logarithmic climb. ${ }^{32}$ Nevertheless, farmers were not worried because they had been assured early on that the GRC technology was durable. ${ }^{33}$ Still, some claimed that the technology was flawed, not because of looming resistance, but as a result of other issues.

\section{DETRACTORS}

As mentioned above, most analyses of the environmental impact of GRCs found an improvement over the multiple herbicides and tillage that they replaced. The most publicized claims of problems with GRCs have centered around plant disease, mineral nutrition, yields, and glyphosate toxicology. Two of these topics, mineral nutrition and plant disease as affected by glyphosate, are dealt with in other papers in this special issue of Pest Management Science. ${ }^{34,35}$ Briefly, despite a few highly publicized papers indicating that glyphosate alters plant mineral nutrition in GRCs and that this and other GRC characteristics result in increased fungal pathogen infestation of GRCs, the preponderance of peer-reviewed literature does not support these theories. ${ }^{34-36}$

Another issue has been whether there is a yield reduction in GRCs attributable to either the GR transgene(s) used or to glyphosate. Some of the early GRC cultivars did not have the more elite germplasms for yield, and in at least GR cotton, the gene for resistance was not expressed highly enough in reproductive tissues to always prevent crop damage from glyphosate in the field. ${ }^{37}$ Furthermore, under some environmental conditions, transient yellowing of soybean leaves by glyphosate application was sometimes observed. ${ }^{36,38}$ This was determined to be a result of the transient effect of the slightly phytotoxic degradation product of glyphosate, AMPA. ${ }^{38}$ Improved gene expression and more elite germplasms have ameliorated early problems with this technology. The incremental gain in yield of soybean, maize and cotton that occurred in the USA before GRCs continued at essentially the same rate after introduction of GRCs. ${ }^{36}$ After considering this lack of influence of glyphosate or the GR trait, a US National Academy of Science study suggested that more research should be carried out in controlled environments with appropriate controls to determine if yields are affected by glyphosate or the GR transgene. ${ }^{39}$ Such studies carried out recently have found no effects of glyphosate use on GRCs or the GR transgene on crop yield. 6,34,40 


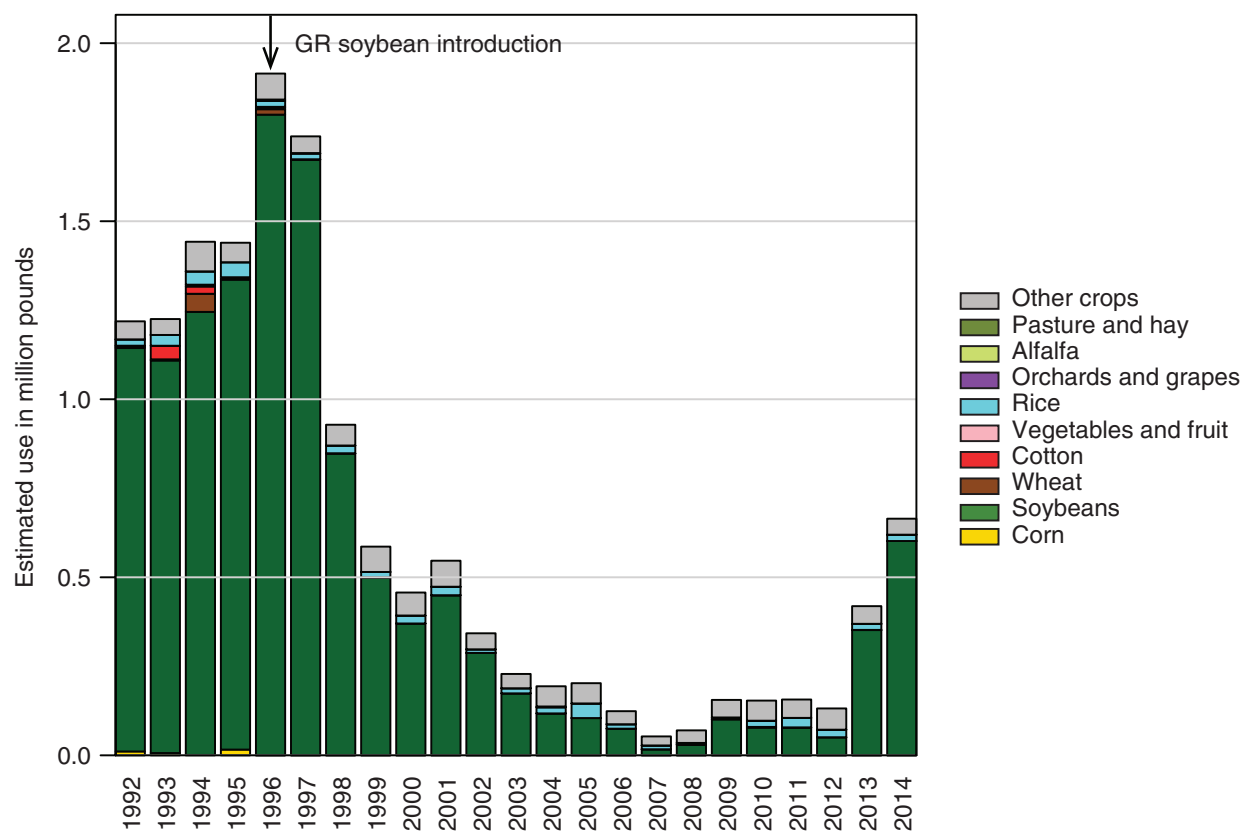

Figure 5. Yearly use of acifluorfen in the USA by crop. ${ }^{2}$

Glyphosate-treated GRC soybeans contain glyphosate and AMPA. ${ }^{41}$ This is documented by the US Department of Agriculture (USDA) Pesticide Data Program, an extensive program that monitors pesticide residues in many crops. ${ }^{42}$ However, this program reports neither glyphosate nor AMPA in harvested GR maize seed, as we (Reddy KN et al., unpublished) have also found. Many studies over decades have found no significant acute or chronic toxicological effects of glyphosate on mammals at realistic potential exposure doses, ${ }^{14-17}$ although there has been controversy based on in vitro studies and/or environmentally irrelevant high in vivo dosages, especially in Europe. The recent US National Academy of Science report on genetically engineered crops came to these conclusions: "..the large number of experimental studies provided reasonable evidence that animals were not harmed by eating food derived from GE crops. ... livestock health before and after introduction of GE crops showed no adverse effects associated with GE crops. The committee also examined epidemiological data on incidence of cancer and other human health problems over time and found no substantial evidence that foods from GE crops were less safe ...". 39 Recent analyses of potential acute and chronic adverse health impacts of glyphosate ${ }^{16,17,43-45}$ corroborate the many past studies that found no significant toxicological problems with glyphosate. ${ }^{14,15}$ A recent study in which glyphosate use by farmers was analyzed in a multivariate regression analysis with 35 health indicators found no effects, whereas changes in blood chemistry parameters that suggested possible adverse effects on renal function levels of serum folic acid correlated with use of other herbicides. ${ }^{46}$ The authors concluded that changing from conventional crops to GRCs would likely benefit farmer health.

A recent analysis of the impact of glyphosate use in GR maize, cotton and soybean on the acute and chronic hazard quotients attributable to herbicides for these crops in the USA indicated that herbicides other than glyphosate account for most of the hazard quotients from herbicide use in these crops. $^{47}$ In maize, acute toxicity decreased dramatically after the introduction of GR maize, while the chronic hazard quotient increased slightly, but $88 \%$ of the maize chronic hazard quotient was attributable to atrazine and mesotrione use. In cotton, the acute toxicity hazard was reduced dramatically after the introduction of GR cotton; however, the chronic herbicide hazard quotient went up, almost entirely as a consequence of diuron use. After maximum adoption of GR cotton, glyphosate accounted for only $0.2 \%$ of the chronic hazard quotient associated with herbicide use. Chronic and acute herbicide hazard quotients associated with herbicide use decreased by 78 and $68 \%$, respectively, between 1990 and 2015, during which US farmers switched from use of many herbicides to mostly glyphosate use, augmented with only a few other herbicides..$^{30,31,47}$

Toxicological issues with glyphosate might be controversial, but an unequivocal major problem with glyphosate use is that of evolved herbicide resistance, a decades-long agricultural challenge associated with many other important herbicides that is found in both conventional crops and HRCs.

\section{DARWINIAN REALITY SPOILS A GOOD THING}

The most unequivocal problem for glyphosate and GRC use has been the burgeoning evolution of resistance to glyphosate in weeds, as a result of the massive selection pressure created by constant and widespread use of this highly successful technology. As of mid 2017, 37 weed species were reported to have evolved resistance to glyphosate, and new GR species are being reported at a current rate of more than two new species per year. ${ }^{48}$ Much of this increase in GR weeds has been in GRCs, where farmers have almost exclusively used glyphosate year after year. ${ }^{49}$ However, continuous use in non-GRC settings (e.g. orchards) accounts for a significant fraction of evolved GR weed species. Some weed scientists predicted what has happened, but even if farmers believed such predictions, the unprecedented ease, economy, and efficacy of this revolutionary technology made the precautionary use of more diversified weed management unacceptable to them. The mindset was to adapt if glyphosate resistance comes. Bonny ${ }^{31}$ provides a detailed analysis of how weed scientists, farmers, and agribusiness have coped with GR weeds. As glyphosate resistance has become 


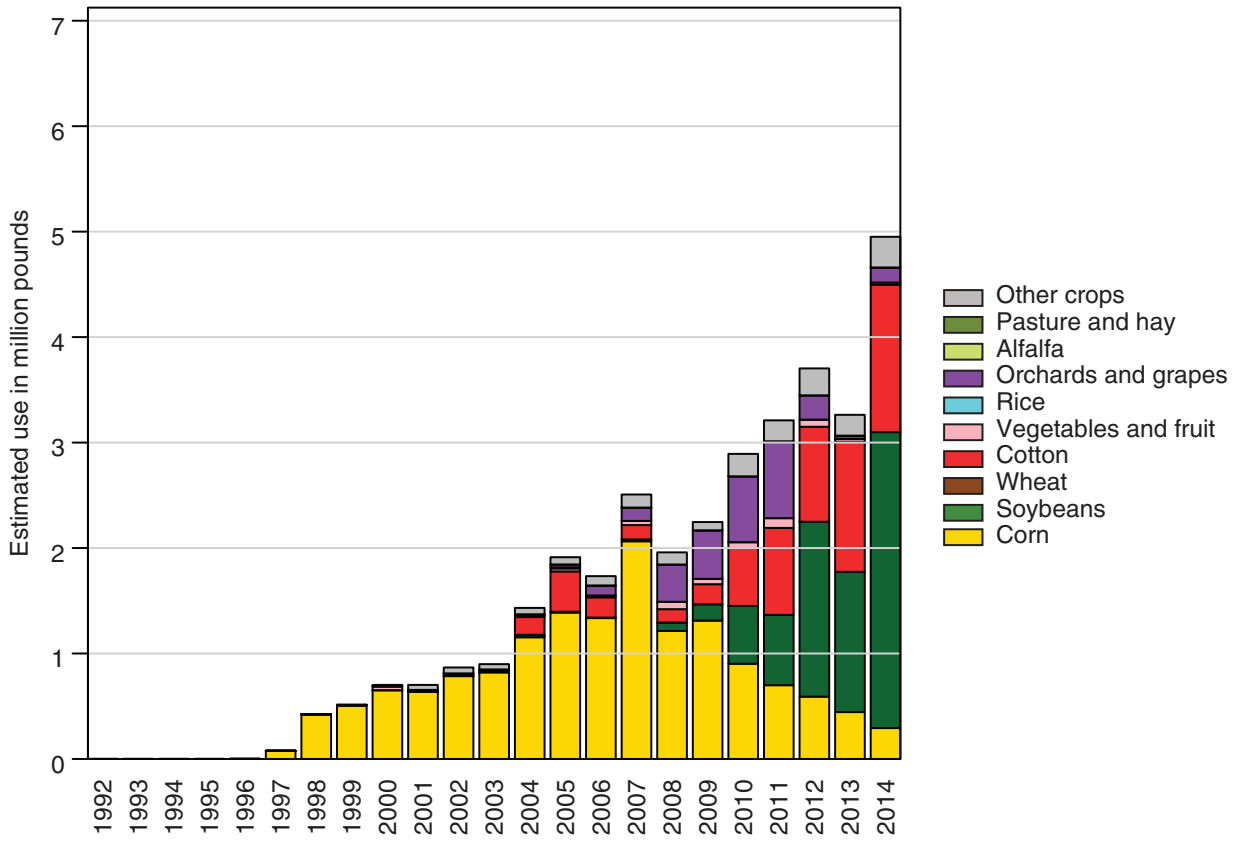

Figure 6. Yearly use of glufosinate in the USA by crop. ${ }^{2}$

more widespread, adoption of weed resistance management practices is becoming more common, ${ }^{50}$ but these practices are still too infrequently used in the absence of GR weeds.

Some of the GR weeds (particularly, Lolium spp., Amaranthus spp., and Conyza spp.) have caused severe problems that have lowered weed management efficacy and significantly increased the cost of weed management. ${ }^{50}$ Farmers with GR weed problems have reinstituted tillage regimes and the use of additional herbicides that control GR weeds. For example, as seen in Fig. 5, the use of acifluorfen in soybeans, which had plummeted with the adoption of GR soybeans, began a slow rise in 2013 for this crop. Thus, evolution of GR weeds is eroding whatever environmental and toxicological benefits have been claimed to have accrued from adoption of GRC/glyphosate technology. ${ }^{51}$

\section{UNEXPECTED PHENOMENA OF GLYPHOSATE}

Two very real, but usually subtle, phenomena have been found with glyphosate over the years. The first is that, although the preponderance of evidence indicates that glyphosate does not promote disease in GRCs, ${ }^{35,36}$ glyphosate can act as a fungicide with some plant pathogens in GRCs. ${ }^{52,53}$ Patents have been issued for use of glyphosate to control crop pathogens, but this use is not on the glyphosate label. This phenomenon has not been studied in detail, and the effect is not likely to be recognized in the field, as the effect is unlikely to be as clear as the effects of a commercial fungicide. This understudied effect would only be seen when the timing of glyphosate application and the exposure to a glyphosate-sensitive pathogen are synchronized for getting adequate amounts of glyphosate to the pathogen for a significant effect. Considering the enormous use of glyphosate over vast areas of HRCs, the unknown benefits of such effects could be substantial.

The second unexpected phenomenon is stimulation of glyphosate-sensitive plant growth at ultra low doses, a phenomenon known as hormesis. ${ }^{54}$ Herbicide hormesis is not exclusive to glyphosate, but it appears to be more pronounced and repeatable with glyphosate than with other herbicides. ${ }^{54}$. Brito et al. ${ }^{55}$ review this topic in this issue of Pest Management Science. We do not know the impact of glyphosate hormesis in the field, but it may be implicated in evolution of GR weeds. ${ }^{55,56}$ In contrast, it could sometimes enhance the growth and/or yield of GRCs if the application rates used for weed management are in the hormetic dose range. To my knowledge, this has not been looked for in carefully designed experiments, but occasionally there is some evidence that this occurs. For example, Williams et al. ${ }^{40}$ found that a recommended rate of glyphosate increased GR sweetcorn ear number and kernel mass, independently of weed control benefits.

\section{THE UNCERTAIN FUTURE OF GLYPHOSATE}

Evolution of GR weeds is likely to be the biggest hindrance to the use of glyphosate in the near future. One could say that the incredible success of glyphosate with and without GRCs has been the source of its potential decline, just as the success and overuse of antibiotics have jeopardized their use. Still, even with GR weeds becoming a costly problem in GRCs, farmers continue to use glyphosate in GRCs because the majority of weed species in these crops are still susceptible, and glyphosate is the herbicide of choice for most of these weeds. The adoption rate continues to be $>90 \%$ in cotton, maize and soybean in the USA, even after GR weeds became a major problem in GRCs (Fig. 4). Glufosinate-resistant crops have been available since 1995, but the glufosinate use rate in major crops has been relatively low since then, although there has been an upward trend in glufosinate use in cotton and soybeans, in large part as a result of the availability of HRCs with both glyphosate and glufosinate resistance (Fig. 6). A short-term solution to the GR weed problem will be HRCs made resistant to old herbicides to which resistance can evolve more easily than to glyphosate. ${ }^{8,51}$ There seems to be no desire to commercialize GR wheat or rice, the two major crops that are still not GR, nor is there evidence for introduction of other GR crops in the USA in the near future, although GR creeping bentgrass (Agrostis 
stolonifera) was recently approved by the USDA for landscape and turf use. In Brazil, a very small amount (ca. 40 ha) of GR eucalyptus is being grown, and GR sugarcane may be introduced eventually, but these additions will not have a significant impact on the use of glyphosate worldwide. In the short term, glyphosate will continue to be the most used herbicide. Unabated increases in GR weed species and the spread of existing GR species are likely to eventually reduce glyphosate use. Discovery of a new broad-spectrum herbicide with a new mode of action that is as effective as glyphosate, along with concomitant introduction of complimentary HRCs, would probably greatly reduce glyphosate use. If such a highly valuable product were to be introduced, I hope that the lessons learned from the loss of utility of glyphosate by its overuse would cause the agricultural community to adopt integrated weed management practices that would prevent or slow the evolution of widespread resistance.

\section{ACKNOWLEDGEMENTS}

I thank Dr Nancy Baker of the US Geological Survey for her assistance with Figs 1, 2, 5 and 6.

\section{REFERENCES}

1 Duke SO and Powles SB, Glyphosate: A once-in-a-century herbicide. Pest Manag Sci 64:319-325 (2008).

2 United States Geological Survey, National Water-Quality Assessment Program, Pesticide National Synthesis Project. [Online]. Available: https://water.usgs.gov/nawqa/pnsp/usage/maps/show_map.php? year $=1994 \&$ map $=$ GLYPHOSATE\&hilo=L [9 October 2016].

3 James C, Global Status of Commercialized Biotech/GM Crops:2016. ISAAA Brief 52, ISBN: 978-1-892456-66-4 (2016).

4 Brookes $\mathrm{G}$ and Barfoot P, Economic impact of GM crops: The global income and production effects 1996-2012. GM Crops Food Biotechnol Agric Food Chain 5:1, 1-11 (2014).

5 Gusta M, Smyth SJ, Belcher K and Phillips PWB, Economic benefits of genetically-modified herbicide-tolerant canola for producers. AgBioForum 14:1-13 (2011).

6 Klümper W and Qaim M, A meta-analysis of the impacts of genetically modified crops. PLoS ONE 9:e111619 (2014).

7 Duke SO, Taking stock of herbicide-resistant crops ten years after introduction. Pest Manag Sci 61: 211-218 (2005).

8 Duke SO, Perspectives on transgenic, herbicide-resistant crops in the USA almost 20 years after introduction. Pest Manag Sci 71:652-657 (2015).

9 Gerwick BC, Thirty years of herbicide discovery: Surveying the past and contemplating the future. Agrow (Silver Jubilee Edition): VII-IX (2010).

10 Duke SO, Why have no new herbicide modes of action appeared in recent years? Pest Manag Sci 68: 505-512 (2012).

11 Calderbank $A$ and Slade P, Diquat and paraquat. in Herbicides: Chemistry, Degradation, and Mode of Action, Vol. 2, ed. by Kearney PC and Kaufman DD. Marcel Dekker, Inc, New York, NY, Ch. 1, pp. 501-540 (1976).

12 Duke SO, Glyphosate, in Herbicides: Chemistry, Degradation, and Mode of Action, Vol. 3, ed. by Kearney PC and Kaufman DD. Marcel Dekker, Inc, New York, NY, Ch. 1, pp. 1-70 (1988).

13 Summers LA, The Bipyridinium Herbicides, Academic Press, London, 449 pp. (1980).

14 Geisy JP, Dobson S and Solomon KR, Ecological risk assessment for Roundup ${ }^{\circledR}$ herbicide. Rev Environ Contam Toxicol 167:35-120 (2000).

15 Williams GM, Kroes R and Munro IC, Safety evaluation and risk assessment of the herbicide Roundup and its active ingredient, glyphosate, for humans. Regul Toxicol Pharmacol 32:117-16 (2000).

16 Williams GM, Aardema M, Acquavella J, Berry C, Brusick D, Burns MM et al., A review of the carcinogenic potential of glyphosate by four independent expert panels and comparison to the IARC assessment. Crit Rev Toxicol 46(S1): 3-20 (2016).

17 Brusick D, Aardema M, Kier L and Williams GM, Genotoxicity expert panel review: weight of evidence evaluation of the genotoxicity of glyphosate, glyphosate-based formulations, and aminomethylphosphinic acid. Crit Rev Toxicol 46(S1): 56-74 (2016).
18 Barrentine WL, Snipes CE and Baker RS, Herbicide application technology, in Weeds of Cotton: Characterization and Control, ed. by McWhorter DG and Abernathy JR. Cotton Foundation, Memphis, TN, USA, pp. 439-514 (1992).

19 Derting CW, Wiper application, in Methods of Applying Herbicides, ed. by McWhorter C and Gebhardt MR. Weed Sci. Soc. Amer. Champaign, IL, USA, pp. 207-229 (1987).

20 Duke SO, Biotechnology: Herbicide resistance. Chap. 218. In Encyclopedia of Agriculture and Food Systems, $2^{\text {nd }}$ Edition, ed. by N Van Alfen. Elsevier, pp. 94-116 (2014).

21 Duke SO and Powles SB, Glyphosate-resistant crops and weeds: Now and in the future. AgBioForum 12:346-357 (2009).

22 Carrer H, Barbosa AL and Ramiro DA, Biotechnology in agriculture. Estudos Avançados 24:149-163 (2010).

23 Oeschger T, Schweikhardt D and Thornsbury S, Regulation of glyphosate-resistant sugar beets: Challenges and uncertainty. Choices 26(3): 6 pp (2011).

24 Bartlett RK, Weed management in Genuity ${ }^{\circledR}$ Roundup Ready ${ }^{\circledR}$ sugarbeet (2011). Proc. Amer. Soc. Sugarbeet Technologists. [Online]. Available: http://assbt-proceedings.org/ASSBT2011Proceedings/ secAAgronomy.htm [6 December 2016].

25 Green JM, The benefits of herbicide-resistant crops. Pest Manag Sci 68:1323-1331 (2012).

26 Gianessi LP, Economic impacts of glyphosate-resistant crops. Pest Manag Sci 64:346-352 (2008).

27 Cerdeira AL and Duke SO, The current status and environmental impacts of glyphosate-resistant crops: A review. J Environ Qual 35:1633-1658 (2006).

28 Brookes G and Barfoot P, Global impact of biotech crops: Socio-economic and environmental effects of the first ten years of commercial use. AgBioForum 9:139 - 151 (2006).

29 Barfoot $\mathrm{P}$ and Brookes $\mathrm{G}$, Key global environmental impacts of genetically modified (GM) crop use 1996-2012. GM Crops 5:2, 1-12 (2014).

30 Bonny S, Herbicide-tolerant transgenic soybean over 15 years of cultivation: Pesticide use, weed resistance, and some economic issues. The case of the USA. Sustainability 3:1301-1322 (2011).

31 Bonny S, Genetically modified herbicide-tolerant crops, weeds, and herbicides: Overview and impact. Envron Manag 57:31-48 (2016).

32 Heap I, Global perspective of herbicide-resistant weeds. Pest Manag Sci 70:1306-1315 (2014).

33 Bradshaw LD, Padgette SR, Kimball SL and Wells BH, Perspectives on glyphosate resistance. Weed Technol 11:189-198 (1997).

34 Duke SO, Rimando AM, Reddy KN, Cizdziel JV, Bellaloui N, Shaw DR et al., Lack of transgene and glyphosate effects on yield and mineral nutrition and amino acid content of glyphosate-resistant soybean. Pest Manag Sci http://doi.org/10.1002/ps.4625 (2017).

35 Hammerschmidt R, How glyphosate affects plant disease development: It is more than enhanced susceptibility. Pest Manag Sci http://doi.org/10.1002/ps.4521 (2017).

36 Duke SO, Lydon J, Koskinen WC, Moorman TB, Chaney RL and Hammerschmidt R, Glyphosate effects on plant mineral nutrition, crop rhizosphere, microbiota, and plant disease in glyphosate-resistant crops. J Agric Food Chem 60:10375-10397 (2012).

37 Pline WA, Viator R, Wilcut JW, Edmisten KL, Thomas J and Wells R, Reproductive abnormalities in glyphosate-resistant cotton caused by lower CP4-EPSPS levels in male reproductive tissue. Weed Sci 50:438-447 (2002).

38 Reddy KN, Duke SO and Rimando, AM, Aminomethylphosphonic acid, a metabolite of glyphosate, causes injury in glyphosate-treated, glyphosate-resistant soybean. J Agric Food Chem 52:5139-5143 (2004).

39 Gould F, Amasino RM, Brossard D, Buell CR, Dixon RA, Falck-Zepeda JB et al., Genetically Engineered Crops: Experiences and Prospects. National Academies of Sciences, Natl Acad Press, Washington, DC, 388 pp, (2016).

40 Williams MM, Bradley CA, Duke SO, Maul JE and Reddy KN. Goss's wilt incidence in sweet corn is independent of transgenic traits and glyphosate. HortScience 50:1791-1794 (2015).

41 Duke SO, Rimando AM, Pace PF, Reddy KN and Smeda RJ, Isoflavone, glyphosate, and aminomethylphosphonic acid levels in seeds of glyphosate-treated, glyphosate-resistant soybean. J Agric Food Chem 51:340-344 (2003).

42 United States Depeartement of Agriculture Pesticide Data Program. [Online]. Available: https://www.ams.usda.gov/datasets/pdp [4 June 2017]. 
43 Acquavella J, Garabrant D, Marsh G, Sorahan T and Weed DL, Glyphosate epidemiology expert panel review: a weight of evidence systematic review of the relationship between glyphosate exposure and non-Hodgkin's lymphoma or multiple myeloma. Crit Rev Toxicol 46 (S1):28-43 (2016).

44 Mink PJ, Mandel JS, Lundin Jl and Sceuman BK, Epidemiological studies of glyphosate and non-cancer health outcomes: A review. Regul Toxicol Pharmacol 61:171-184 (2011).

45 Williams AL, Watson RE and DeSesso JM, Developmental and reproductive outcomes in humans and animals after glyphosate exposure: A critical analysis. J Toxicol Envron Heath 15B:39-96 (2012).

46 Zhang C, Hu R, Huang J, Huang X, Shi G, Li Y et al., Health effect of agricultural pesticide use in China: implications for the development of GM crops. Sci Rep 6:34918 (2016).

47 Kniss AR, Long-term trends in the intensity and relative toxicity of herbicide use. Nature Commun https://doi.org/101037/ncomms14865 (2017).

48 Heap I, International Survey of Herbicide Resistant Weeds. [Online]. Internet. Tuesday, June 6, 2017. Available: http://www.weedscience .org [9 May 2017].

49 Duke SO and Heap I, Evolution of weed resistance to herbicides. What have we learned after 70 years? In Biology, Physiology and Molecular
Biology of Weeds, ed. by Jugulam M, CRC Press, Boca Raton, FL, pp. 63-86 (2017).

50 Livingston M, Fernandez-Cornejo J, Unger J, Osteen C, Schimmelpfinnig D, Park T et al., The economics of glyphosate resistance management in corn and soybean production. USDA-ERS, ERR-184, Washington, DC, 54 pp (2015)

51 Green JM, The rise and future of glyphosate and glyphosate-resistant crops. Pest Manag Sci http://doi.org/10.1002/ps.4462 (2017).

52 Feng PCC, Baley GJ, Clinton WP, Bunkers GJ, Alibhai MF, Paulitz TC et al., Glyphosate inhibits rust diseases in glyphosate-resistant wheat and soybean. Proc Nat Acad Sci USA, 102:17290-17295 (2005).

53 Samac DA and Foster-Hartnett D, Effect of glyphosate application on foliar diseases in glyphosate-resistant alfalfa. Plant Dis 96:1104-1110.

54 Belz RG and Duke SO, Herbicides and plant hormesis. Pest Manag Sci 70:698-707 (2014).

55 Brito IPFS, Tropaldi L, Carbonari CA and Velini ED, Hormetic effects of glyphosate on plants. Pest Manag Sci http://doi.org/10.1002/ ps.4523 (2017)

56 Belz RG and Sinkkonen A, Selective toxin effects on faster and slower growing individuals in the formation of hormesis at the population levels - A case study with Lactuca sativa and PCIB. Sci Total Environ 566-567:1205-1214 (2016). 